\title{
The Supercargo in the China Trade about the Year 1700
}

TWO hundred years ago the supercargo was an important 1 person on a ship trading to the Indies. The ship went exploring to new countries; there were no banks of exchange, and her owners had no correspondents in foreign ports ; they losded on the ship what was required, in goods or in money, to buy a cargo of the products of the foreign country ; and, as they could not go in person, they must have a representative on board who was qualified to sell his 'stock', to exchange his money for the currency of the country, and to buy his 'investment' of such quality and at such prices that the commodities could be sold at a profit on the ship's return to its home port. Besides this mercantile qualification, he must be capable of dealing with persons of rank and dignity. In one port the principal trader might be the king of the country (such a trader was the king of Tongking ${ }^{1}$ ); in another he might be the admiral commanding the naval defences, as at Mindanao in $1686,{ }^{2}$ or the general commanding the garrison, as at Amoy in $1684 ;^{3}$ in another the merchants with whom he must trade were only the commercial representatives of the highest officials, as at Canton in $1699,{ }^{4}$ or one merchant might have the imperial commission to monopolize the trade with foreign ships, as at Chusan, Amoy, and Canton in 1702-4.5 The supercargo needed diplomatic ability to cleal with all suoh extraordinary situations; not simply the courage to resist extortionate demands, but the skill to conduct a trade notwithstanding that suoh demanda were made.

The first requirement for a superoargo on English ships trading to China wes a knowledge of Portuguese. For over a century from 1517, the only European ships to visit China were Portuguese, and their language became, to some extent, the lingua franca of the cosst. The Hollanders settled in Taiwan

1 Diary of Supercargo of the Zaut, 1672 (India Office Records, China). In the subsequent notes I shall rofer to supercargoes' diaries in the seme series by the name of the ship and date.

- Loyal Advendwre, 1688-6. - Deligh, 1684. Macelesfield, frigato, 1698.

- Cauterbury, 1702 (at Amoy) : Renl, 1704 (at Canton); Diery of the Counoil for China, 17(r2, India Office Recorrls, China (Chusan). 
(Formosa) in 1624, and traded thence to ports in Fukien; they took interpreters from the Chinese at Batavia who spoke Dutch; and the French found everywhere friendly missionaries who could interpret for them. The English, coming first in 1637, could have no communication with the Chinese except through an interpreter who knew both Portuguese and Chinese. This was sometimes an untrustworthy Chinese who could speak Portuguese, sometimes a low-class Portuguese who could speak Chinese, more commonly a half-breed, who had acquired the one tongue from his father, and the other from his mother. Under these conditions aelling a piece of cloth or buying a bale of silk required only ordinary business acumen; but the disentanglement of difficulties, such as befell every ship, demanded the greatest diplomatic ability in the supercargoes; and the absence of that ability, and even of honesty and loyalty, in the interpreters made the diffoulties of the supercargoes almost insurmountable.

From about 1690 the English ships obtained much friendly advice and help, in their more serious difficulties, from the French priests. The cordial relations between these priests and the English East India Company were recognized on both sides. The priests were frequently given a free passage to Earope in the Company's ships; and when the persecution initiated by the Emperor Yungcheng in 1724 drove them from their churches at all places except Canton, Père de Goville depasited the sum of 10,000 pagodes $(£ 4,500)$ with the English Company in London, on condition that the Company's agents should pay 600 pagodas a year to the priests in Canton.' From about 1715 the Chinese merchants themselves learned the curious patois known as pidgin English', which thereafter became the lingua franca of the China trade.

Selling the 'stock' carried out from England required but little ability. The law required that not less than one-tenth of the stock carried by each ship from England should consist of goods 'the growth, produce or manufacture of the kingdom', and until the middle of the eighteenth century no ships going to China could dispose of more than that proportion of English goods. Lead was 'as good as money', and each ship took usually from 40 to 60 tons of it; woollen goods were sold with difficulty, without profit, and in small quantities; and China asked for nothing else that was English. Sometimes, but less often as time went on, ships from Englend went, on the way out, to Sumatra (Benkulen) of to Borneo (Banjarmassin), and loaded from 50 to 100 tons of pepper for sale in China. Generally speaking, however, at the period we are now describing, nine-tenths of

1 Diary of the Counois for China, 1702; Macelesfield, 1724. 
each ship's stock consisted of silver sent from England. From 1720 to 1750 the silver on each ship seldom constituted less than 98 per cent. of her stock; but from the latter date English woollens began to find a wider market at 'dumping' prices; they were the means of 'laying down the dollar'.

The export from England of English silver coins was strictly prohibited. The silver sent was sometimes, but not often, in bars ; almost invariably it was in minted coins. In the order of frequency they were: (1) Pillar dollars, ryals of eight, or pieces of eight, minted at the royal mint of Seville; current in the China trade for three centuries; 95 'touch' of the Chinese standard. (2) Mexico dollars, minted at the viceregal mint of Mexico; from 1855 the ordinary currency of the treaty ports of South China ; 84 'touch'. (3) Duccatoons, minted by the mint of Venice ; 96 'touch'. (4) French crowns, minted by the royal mints of France; 94 'touch' if bearing three crowns on reverse, otherwise 93 or 92 'touch'. (5) Rix-dollars, of 90 'touch'. I have not ascertained whether these were from Scandinavian or German mints. These were usually packed in chests containing each 4,000 coins, weighing net $290 \mathrm{lb} .8 \mathrm{oz}$. Troy $=3,488 \mathrm{oz}$. $=$ 108,489 grammes. In 1729 new Seville dollars arrived at Canton of which the 'touch' had been lowered to that of the Mexico dollars-04. From some date between 1750 and 1760 both these dollars were rated at 92 'touch'; and in 1775 both mints issued dollars bearing the king's head in place of the arms of Spain. These 'head dollars' were rated at 90 'touch', and when paid by tale passed at $\$ 100=$ Tls. 72 .

Dollars never passed into Chinese hands by count, but always by weight in Chinese liang or taels, modified by the touch. These taels differed in weight at different ports. At Chusan there were two taels in ordinary use-the Tsaoping of 567.3 grains (36.76 grammes), and the Kiangping of 555.3 grains (35.98 grammes); but in which the supercargoes had to pay is not recorded. At Amoy the market tael was 570.0 grains (36.94 grammes). At Macao the market tael was 577.1 grains (37.40 grammes). At Canton the Szema trel is to-day 578.3 grains ( 37.48 grammes); in 1846 it was 378.0 grains (37.45 grammes); but in 1699 one supercargo in making payments found it to be 680.8 grains (37.64 grammes), and in 1724 another found it 581.95 grains (37.71 grammes); but consistently for a hundred years, 17301834, the fixed equivalence was $120.8 \mathrm{oz}$. Troy $=100$ teels weight (the trel being thus 579.84 grains). This is the weight, but the value was further affected by the 'touch' of silver. This was either 'sycee', nominally 1,000 fine (being pure silver of the Chinese stendard), or 'current ' silver which varied with each tael ; at Chusan the Tsaoping tael of value was 997 fine, and the Kiang- 
ping tael was 991 fine; at Canton and at Amoy the current silver was 940 fine. If the payment was for government dues it was in 'sycee ', 1 if for goods it was in 'current' silver. The 'touch' of foreign coined silver was fixed and recognized at the rates given above; bars and shoes or ingots varied one with another, and all had to be reduced to the 'touch' of the tael of currency in which payment was made."

The complication was especially marked in buying gold, which was cheap in China about 1700 , being only two-thirds of the European mint price. Gold came in shoes of nominally 10 taels weight, and was sold on the basis of being 94 'touch'; its price in silver was quoted at so much 'above' or 'below touch'. Thus

10 taels of gold, of 94 touch, at 'touch for touch ' $=94$ taels silver

$\begin{array}{llll}", \quad, \quad & \text { at ' } 3 \text { above touch' }=97 \\ " & \quad, & \text { at ' } 3 \text { below touch' }=91 \quad "\end{array}$

Thus, in the case of a shoe of gold, 97 touch, weighing 9.85 taels, sold at 4 above touch, paid for in duccatoons :

9.85 taels of 97 touch is 10.164 taels 94 touch;

at 4 above touch is 98 taels silver for 10 taels gold,

or 99.607 taels current silver of 94 for this shoe of gold ;

paid for in duccatoons 96 touch,

is 97.532 tacls weight of duccatoons. ${ }^{3}$

Besides having this complete mental equipment of the banker, the supercargoes had to know the quality of goods. They must know whether raw silk offered to them was worth 150 taels a picul, or only 145; whether the tea was of such quality that they could pay $2 s$. 6d. a pound, or must pay only $1 s$.; whether, for their heavy cargo, copper at 15 taels or 'tutenague' (spelter, zinc) at 6 taels a picul was the more profitable purchase; whether the weft of woven silks should have the same strength as the warp; whether China root was better white, or tinted pink; whether vermilion at 42 taels or quicksilver at 42 taels was the better purchase. They also had to take the responsibility of deciding whether they should advance as much, perhaps, as 50,000 taels to a merchant of whom they knew very little, in prepayment for goods which would not be delivered until four months later. On their arrival at a port they had to decide whether to resist the exactions which were threatened to their trade, and go on to another port, where they might find the conditions no less bad; or whether they should take their ships in, and trust to their diplomatic skill to gain better terms by negotiating with the officials and the merchants.

'The parity of exchange of the Canton tecl of 'sycee' was then 6s. 8d.

: Mlurio, Trade aid Adisinititation of China, cap. 5

1 Talpote. 1722 (at Cantan). 
All these qualities made it necessary that the supercargoes should be men of ability, of good education, and of incorruptible honesty. They were paid salaries which, to modern ears, sound ludicrously inadequate. The chief of the Amoy factory in $\mathbf{1 6 8 1}$ received a salary of $f 80$ a year; his colleagues, the 'junior

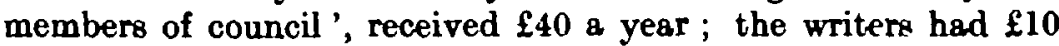
a year. When the Taiwan factory was subordinated to Amoy,

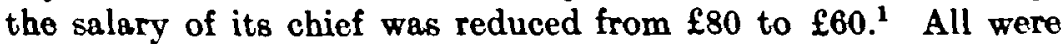
lodged and fed at the expense of the Company. As an illustration of the nominal salaries and real wages of servants of the Company, we may take note of the staff sent in 1699 to open a factory in Borneo :

\begin{tabular}{|c|c|c|c|c|c|}
\hline & & $\mathfrak{E}$ & & & f s.d. \\
\hline Chief of factory & . & 100 & Chief shipwright & or master & \\
\hline Merchant (second) & & 60 & builders & esch & 60 \\
\hline Merchant (third) & • & 60 & Ship carpenters & ,. & 40 \\
\hline Factor (fourth) & . & 40 & Chief smith & & 40 \\
\hline Factor (fifth) & 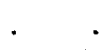 & 40 & Smith & & 336 \\
\hline Writerg (four) & . each & 10 & Sawyers & each & 35 \\
\hline
\end{tabular}

It may well be asked how men of such marked ability and of such varied attainments could be attracted to the Company's serrice, and how, being in it, they could be expected to be loyal, zealous, or even honest. In England and in Europe generally at that period, as in China then and to-day, the salary of a government official was but a small part of the recognized and legitimate emoluments of his office. Fees, perquisites, presents, exactions, bribes, all contributed to make up the true value of the office.' The East India Company was modelled on government lines, and its servants were paid on a government scale until well into the nineteenth century; but the Company could not allow its servants to supplement their recognized selaries by the same methods as were customary with government officials. To ensure their honesty, to stimulate their zeal, to confirm their loyalty, the Company granted every possible indulgence to its servants; it usually allowed them some private trade, under such limitations as would safeguard its own interests ; sometimes it granted them a commission on the prime cost of the investment made in China, and sometimes it gave them a share in the stock, both goods and silver, which the ship took from England.

The tendency at first, in accordance with the practice of the time, was for the Company to give the supercargoes nothing from its own aspital, but to allow them to risk their own money and to make such profit for themselves as they made for the

1 Barnardiston, 1680-1.

- Court to Council for Borneo, India Offico Records, December 1698. 
stock provided by the Company. In the year 1674 the Company

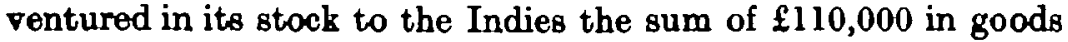
and $£ 320,000$ in silver, a total of $£ 430,000$, bringing home an investment valued on arrival in England at $\mathfrak{\$ 8 6 0 , 0 0 0}$; in that same year, by the same ships, the supercargoes and the captains and officers of the ships took from England as private ventures the sum of $£ 45,000$ in goods and $£ 90,000$ in silver, a totel of $\$ 135,000$, nearly one-third of the Company's public venture. ${ }^{1}$ A practice such as is indicated by these figures was, obviously, one which might easily lead to abuse, and would certainly cut into the profits of the Company; but the objections to it were more manifest in connexion with the private trade of the captain and officers of the ships, than with that of the supercargoes. On many occasions the supercargoes had cause to complain that the captains engrosed profitable trade which ought to have gone to the Company, the most usual ground of complaint being that, by underhand means, they had induced the Chinese merchants to insist .on paying them in commodities (such as silk, tea, \&c.) instead of gold, which by regulation ought to have formed their investment ; and, in 1715, the court of directors complained that, in the previous year, the captains and officers of their ships had brought to England no less than 20,000 pounds of tea, to the serious detriment of their own trade in tea, which at that time did not much exceed that amount. ${ }^{2}$

Generally all the Company's servants were prohibited from trading in the main staples which constituted the principal part of its own trade ; in China, silk was, of course, always prohibited; and in 1686 the court direoted that: 'as the Chyna Trade was beooming more promising, Teas and Spices were, in future, to form Part of the Company's Imports, and not to be articles of Private Trade.' 3 During its whole history the tendency of the Company was to restrict the private trade, as far as possible, to silver, coral, and amber outwards, and to gold and musk from China to India, and diamonds from India to England, as return investments, since they took up little tonnage.

The Company was, however, always chary of imposing any restraint on the activities of its supercargoes, and in that same year, 1686, the court wrote complaining of the conduct of the Madras presidency, ${ }^{4}$

in abuaing the order for the purchase on the Company's account of Chyna Goods brought in Private Trade thither. When the Court gave the order, they did not conceive that their Servantw would be buyers and sellers both.

' R. Wissett, Compendium of East Indias Affairs (London, 1801).

2 Court to Council for Chin (ship Swanna), December 1716.

- Court to Medrag Presidency, Ootober 168a. 
At the same time the court wished to 'encourage them in all good wayes', and for that purpose

We give you leave for the future to send us any intire Cargo of Chyna Goods proper for Europe Mlarketts of your own, or your own in compeny with any Natives or others, at the first cost in Chyns, to take your satisfaction there out of our Cash, when the Goods are shipt for England (but not before) that you may have your Stocks to goe on with again, on a new royage, on this conditon, that if the said Chyna Cargoes of yours, \&c., make not the said first cost here, free of single freight, and all charges, the adventure of the Sea from the Fort [Madras] hither, in such case shall be ours, but the loss at home, if any happen upon Sales, shall be yours. . . . And if any gain arise by such Chyns Goods here, 20 \% Cent. of the profitt thereof shall be ours in consideracon of our running the hazard of the sea, generall charges of the Company, and disbursem aforehand of our money in India ; the rest of the gain justly, whatever it proves to be, shall be yours, and immediately returned you in Dollars, by the first Ship after the sale of such Chyna Goods here; this we say in times of Peace : but if a Dutch war should happen, we shall in time of such war, expect 40 Cent. of the profitt to the Company for running the risque \&c., as aforesaid. .. The Company will sell the Goods here by the Candle.

This proposal seems sufficiently liberal, even in our eyes, unaccustomed as we are to all forms of private trade in competition with the trade of employers.

Some of the East India Company's ships belonged to themselves, while others were chartered, and the conditions under which thelatter were managed were sometimes affected by the terms of the charterparty. The allowance for private trade made for the ship Eaton, chartered by the Company for Chins in 1699, and the limitations placed on it, may serve as an example of the privileges granted to such ships, over and above the remuneration to the supercargoes. ${ }^{1}$

Privale Trade. The Court have allowed by the Charterparty $\$ 3500$ to be sent out by the Owners, Master and Ship's Company of the Eaton; whereof $£ 1500$ may be carried out and brought home in such Commodities as they please, on condition that her Captain do not sell or buy in China without the Concurrence of the Factory. The remaining $£ 2000$ is [to be] sent out in Silver ; and the Court permit the proceeds to be returned from Chins in Gold, or otherwise may be sent to Coromandel, consigned to some of the Company's Factors to be returned thence in Diamonds by a Company's Ship, the Proprietors paying what others pay.

Such generous terms were not always given to the owners of chartered ships, but the officers of all ships were treated at first in what seems to be a liberal fashion. In time this was found to work to the disadvantage of the Company, and this branch of the private trade was strictly regulated, until, by 1720 , the captains and officers, who in 1714 had brought 20,000 lb. of tea

1 Court to Council for China (going to Chusan), November 1690. 
to England on their own account, were limited at first to 3 per cent. of the ship's tonnage, and later to a total of two hundredweight (224 lb.) for every hundred tons of the ship's tonnage ; the ships of that time were usually of 850 tons burthen, and under this rule their private ventures in tea might amount to seven hundredweight. It was, however, the cargo space of the ship that was most carefully safeguarded; and in their cabins and berths, so long as they did not encroach on the tonnage capacity of the ship, they might still bring ventures which were not articles of commerce, such as fans, ivory carvings, embroideries, and articles having a value as curiosities zreater than their intrinsic value. Restrictions placed from time to time on the private ventures of captains and officers were not long retained; and in 1729 we find the captain of the ship Ly/nn having

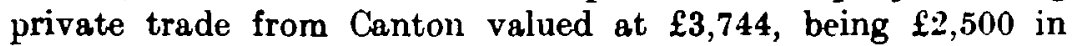
gold and $\mathfrak{f 1 , 2 4 4}$ in goods, including $7,750 \mathrm{lb}$. of tea. ${ }^{1}$ The Company was, however, always struggling to check this tendency.

The supercargoes were, on the contrary, treated more and more generously in the way of allowances, in proportion as their private trade was restricted. At first, as has been said, their zeal was stimulated and their efforts were rewarded only by the private trade allowed, with, apparently, no unreasonable restrictions imposed. Then some limitation was placed on the articles which might form part of the private trade, and on the proportion of the ship's carrying capacity which might be taken up by it ; but the court had no wish to diminish the reward which their supercargoes might earn, and what they took away with one hand they gave with the other. At first, as they began to limit the amount of private trade, they gave their supercargoes a commission on the prime cost of the return investment by the ship. Against the payment of unduly high prices, the court trusted to the honesty and loyalty of their supercargoes, and they have never been impeached; the court's principal aim was to stimulate their supercargoes' zeal, and so to secure a full lading of the most profitable commodities. During the seventeenth century, when the individual ship formed the unit of a venture, the number of supercargoes on each ship was usually three, and the commission paid was generally either $3 \frac{1}{2}$ or 4 per cent.-divided to give the chief $1_{4}^{3}$ per cent., the second 1 or 1 per.cent., and the third \& or 1 per cent. By the Aurungzebe, at Amoy in 1702, the return investment was invoiced at 122,150 taels, and the commission debited to the Company for division between the three supercargoes amounted to 4,275 taels. When the commission was only $3 \frac{1}{2}$ per cent. they had in addition some private trade, but its amount on the Aurungzebe is not recorded. ${ }^{*}$

1 Disry of the Council for China, 1729

'A urungrehe, 1702 (at Amov). 
From the year 1700 the system of paying commission became less common, and the Company made its supercargoes partners in the venture in which they were engaged in common. A certain amount of private trade was still allowed, but the principal part of their reward was to come from a specified portion of the ship's stock, which was assigned to them. In 1698 the English East India Company chartered the Macclesfield frigate, 250 tons; and, as she was a chartered ship, some provision was made also for her owners and officers. She took in London a stock of $£ 5,475$ in goods and $£ 26,611$ in silver, total $£ 32,086$; of this sum $£ 25,036$ was 'for account of the Hon'ble English Company',

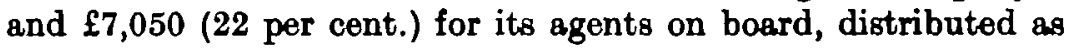
follows : ${ }^{1}$

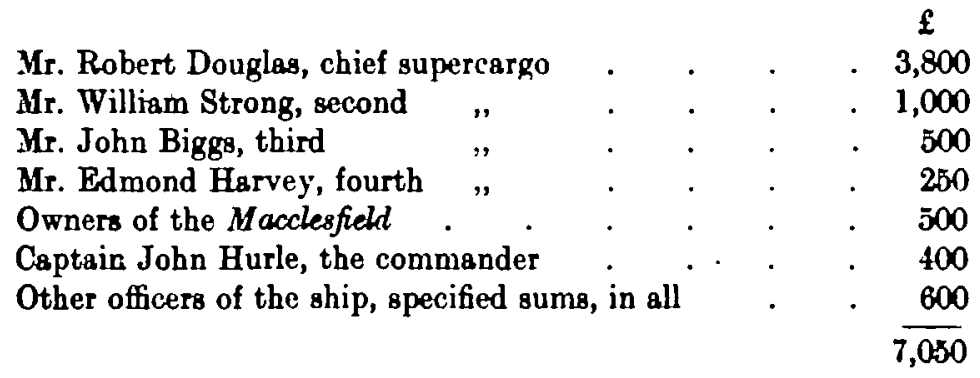

In addition to their private ventures, which were strictly limited, this amount of capital was provided by the Company, and its agents were to have the profit realized on the return of the ship to London.

In 1715 the Company made a change in its practice. Each separate ship was no longer to form a separate venture, with her account and the transaotions connected with her cargo kept independently. On the arrival of the ships at Canton, the supercargoes on board were in future to form one council, one of them being designated as chief, the others having a prearranged order of precedence; but all orders, accounts, and decisions were to be signed by all the members of the council, and only the cargo accounts were kept separate for each ship." For the season of 1722 , by which time the system had taken definite shape, four ships were dispatched to Canton, having on board seven supercargoes in all, who on arrival joined together to form the council. The reward for their efforts was granted by the court in three forms : ${ }^{3}(a)$ 'Allowance' of a portion of the Company's stock on the ships, from which the profits were to be given to the superaargoes in certain proportions, as had been done with the Macclesfield frigate cited above. (b) 'Permission' to each to carry out a certain sum in foreign silver,

- Maccksfield, frigate, 1699 (at Canton).

- Court to Council for China, Decemher 17j5.

- lbid., December 1721 
and to bring back in gold the investment from that sum. (c) 'Privilege' of a separate venture, in goods both ways. The amount of each of these grants to each member of the council of 1722 was as follows:

\begin{tabular}{|c|c|c|c|c|c|}
\hline & $\begin{array}{c}\text { Allowance. } \\
£\end{array}$ & $\begin{array}{c}\text { Permission. } \\
£\end{array}$ & $\underset{f}{\text { Pritiloge. }}$ \\
\hline \multicolumn{3}{|c|}{ Mr. James Naish, chief nember } & 3,000 & 1,500 & 200 \\
\hline MIr. Newman, & 2nd & .. & 1,800 & 900 & 150 \\
\hline Mr. Savage, & 3rd & 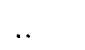 & 1,800 & 900 & 150 \\
\hline Mr. Pratt, & 4th & .. & 1,200 & 600 & 100 \\
\hline Mr. Turner, & 5th & .. & 1,200 & 600 & 100 \\
\hline Mr. du Bois, & 6th & .. & 1,200 & 600 & 100 \\
\hline \multirow[t]{2}{*}{ Mr. Talbot, } & $7 \mathrm{th}$ & ,. & 800 & 300 & 100 \\
\hline & & & 11,000 & $\overline{\mathbf{5}, \mathbf{4 0 0}}$ & $\overline{900}$ \\
\hline
\end{tabular}

The Company's stock on the four ships amounted to $£ 141,828$, at least nine-tenths in silver, which consisted of 80,000 duccatoons and 360,000 pillar dollars, in so far as the accounts disclose the amounts used for buying the return investment. For the season 1724, owing to the fear that China might be in a disturbed state in consequence of the death of the Emperor Kanghi, only one ship was dispatched to Canton, having on board two superoargoes. This number was never considered sufficient for a council, and to make it up to three the captain of the ship was added to it. The rewards were in the same form as in $1722:{ }^{1}$

$\begin{array}{ccc}\text { Allowance. } & \text { Permission. } & \text { Pritilege. } \\ \mathfrak{L} & \mathfrak{f} & \mathfrak{1} \\ 1,500 & 10,000 & 150 \\ 1,000 & 2,000 & 100 \\ 500 & \underline{\text { none }} & \text { none } \\ \frac{12,000}{3,000} & 250\end{array}$

The Company's stock on board was $£ 50,369$; at least nine-tenths being in silver. Under the permission Mr. Pitt carried to Madras gold which realized 32,783 pagodas $(£ 14,752)$, and $\mathrm{Mr}$. Nicholson 6,483 pagodas $(\mathfrak{2 , 9 1 6 )}$, each paying to the Company 3 per cent. as freight.

In 1721 all the supercargoes of four ships were given the 'allowance' and the 'privilege', but, in lieu of the 'permission', they had the option of paying a definite additional sum (in the case of the chief $\$ 1,000$ each) into the Company's stock on board, and on this the court guaranteed them 80 per cent. profit, subject only to the ship's safe return to England. ${ }^{2}$ This we may assume, then, to have been the value of the 'allowance' given to the supercargoes, since in all cases they were subject to no charge for freight, demurrage, or factory charges. The 
profit on the 'privilege ' would depend on the taste and judgement of the adventurer ; a richly jewelled and enamelled watch. or an ingenious flint-and-steel apparatus, might attract buyers in Canton; a tastefully painted fan, a dainty ivory carving, a splendid embroidered robe might find in London buyers willing to give pounds for taels cost - profit of 200 per cent. Given good judgement, it may safely be estimated as probable that a venture of $£ 100$ might realize $£ 200$ in Canton, and those $£ 200$ invested there might in turn realize $£ 400$ in London-a profit of only 100 per cent. on each transaction.

From the year 1731 the court added a fourth form of rewardadditional to the others-in the shape of commission on the prime cost of the return investment ; this was regularly 5 per cent. of the cost of the cargoes of all the ships entrusted to the council's care, and was divided between its members in fixed proportions. From the sesson 1734 this was increased to 5 per cent. of the price realized at the Company's sales in London-practically doubling its amount. The other three forms were still retained, but later on, between 1750 and 1760 (some of the records arc missing), they were suppressed except for some small privilege in the way of private trade. The amount of the 'salary' of supercargoes ut this period cannot be ascertained; but writers, instead of

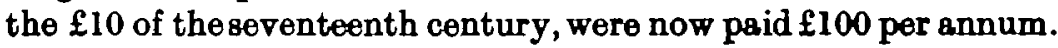

For one China voyage the supercargoes gave three years to the Company's service; in that time their table was provided for them during twenty months; fourteen to fifteen months were spent on the voyage out and home; sirteen months were a rest period in England, and during six months they were subjected to a constant strain of trying work and intense anxiety. As reward for this, Mr. Naish and Mr. Pitt, mentioned above, may be assumed to have received the following sums :

\begin{tabular}{|c|c|c|}
\hline Capital to be provided & $\begin{array}{c}\text { Mr. Naish. } \\
£ \\
\quad 1,700\end{array}$ & $\begin{array}{c}\text { Mr. Pitt. } \\
\{ \\
10,150\end{array}$ \\
\hline Profit from allowance & 2,400 & 1,200 \\
\hline permission & 600 & 4,000 \\
\hline privilege. & 600 & 450 \\
\hline \multirow[t]{2}{*}{ Salary at $£ 80$ for three years } & 240 & 240 \\
\hline & $\overline{3,840}$ & $\overline{8,890}$ \\
\hline
\end{tabular}

These supercargoes, thus provided for, formed the training school from which were taken the select committee at Canton, 1780-1834, who were the finest representatives that England could have desired of her mercantile community; and to the select committeo succeeded the merchant princes of China of the nineteenth century.

Hosea BaLLOU Morse.

vOL. XXXVI. - NO. CXLII. 